\title{
LATIHAN PENINGKATAN KEMAMPUAN BIOMOTOR (KELINCAHAN, KECEPATAN, KESEIMBANGAN DAN FLEKSIBILITAS) DENGAN TEKNIK LARI (SHUTTLE RUN, ZIG-ZAG, FORMASI 8) PADA PESILAT
}

\author{
Bambang Trisnowiyanto \\ Politeknik Kesehatan Surakarta Jurusan Fisioterapi
}

\begin{abstract}
Biomotor Components (Agility, Speed, Flexibilty, Balance), Pencak Silat Athlete. Biomotor such as agility is one of components must had had been own by athlete as physical condition indicator for exellence performance in competition. Agility perform with abilty change of direction and body position in fast and exact at movement without lossing balance and conscious of body position. The purpose of the study was to know influence of agility exercise model for agility, speed, flexibilty and balance in pencak silat athlete. Also to know whereas the efective model of agility exercise can improve physical ability of pencak silat athlete. This research is quantitative research, with quasi experiment design three treatment counterbalance-balance. Data analyses uses Wilcoxon test and Kruskal Wallis test. For measure improvement uses mean different. The significance satandart is $p=0.05$ (5\%). Research result are: There is significant comparation between shutle run, zig-zag run, zig-zag combine 8 numeral run, for agilty and speed ( $p<0.05)$, shutle run useful for improve balance and speed, zig-zag run useful for improve agility and zig-zag combine 8 numeral run usefull for improve flexibility.
\end{abstract}

Key Words : Biomotor Components (Agility, Speed, Flexibilty, Balance), Pencak Silat Athlete.

Abstraks : Komponen Biomotor (Kelincahan, Kecepatan, Keseimbangan, Fleksibilitas), Atlet Pencaksilat (Pesilat). Kelincahan, kecepatan, keseimbangan dan fleksibilitas adalah merupakan komponen biomotor yang harus dimiliki para atlet untuk dapat tampil prima dalam suatu pertandingan. Salah satunya kelincahan adalah suatu kemampuan tubuh untuk merubah arah dan posisi tubuh dengan cepat dan tepat pada waktu sedang bergerak, tanpa kehilangan keseimbangan dan kesadaran akan posisi tubuhnya. Tujuan Penelitian ini adalah untuk mengetahui pengaruh model latihan kelincahan pada kelincahan, kecepatan, kelentukan dan keseimbangan atlet pesilat, serta untuk mengetahui model-model latihan kelincahan yang mana yang efektif dapat meningkatkan kemampuan fisik atlet pencak silat atau pesilat. Penelitian ini merupakan penelitian kuantitatif, dengan desain penelitian quasi eksperimental three treatment counterbalance-balanced. Analisa data dengan uji Wilcoxon dan uji Kruskal Wallis. Hasil perlakuan dan kaitan pengaruhnya diketahui dengan menguji perbedaan inter dan antar kelompok. Untuk mengetahui peningkatan atau kemajuan dengan mean diferrent. Batas kemaknaan hasil uji statistik adalah $\mathrm{p}=0.05$ (5\%). Hasil penelitian menunjukkan: terdapat perbedaan bermakna antara latihan lari bolak-balik, lari zig-zag dan lari zig-zag kombinasi angka 8 terutama pada kelincahan dan kecepatan $(\mathrm{p}<0.05)$, metode latihan lari bolak-balik berguna untuk meningkatkan keseimbangan dan kecepatan, metode 
latihan lari zig-zag berguna untuk meningkatkan kelincahan, dan metode lari zig-zag kombinasi angka 8 berguna untuk meningkatkan fleksibilitas.

Kata Kunci : Komponen Biomotor (Kelincahan, Kecepatan, Keseimbangan, Fleksibilitas), Atlet Pencaksilat (Pesilat).

\section{PENDAHULUAN}

Pencak Silat sebagai salah satu seni budaya yang diwariskan oleh nenek moyang bangsa Indonesia telah menyebar ke seluruh pelosok dunia (Maryun Sudirohadiprojo, 1982; Sucipto, 2001: 27). Bahkan telah dipertandingkan dalam even-even olah raga baik tingkat nasional, regional maupun tingkat internasional, seperti PON, SEA GAMES, Kejuaraan Internasional dll.

Prestasi pencak silat Indonesia akhir-akhir ini mengalami kemunduran yang cukup berarti. Hal ini sesuai realita yang ada pada Kejuaraan Internasional Pencak silat Tahun 2002 di Penang, Malaysia, yang semula mampu mendulang medali emas kurang lebih 80$90 \%$ (9-11 medali emas) sekarang hanya mampu kira-kira $50 \%$ (6 medali emas) saja. Hal ini banyak faktor yang mempengaruhi prestasi ini, diantaranya teknologi, keadaan sosial politik, dan pembinaan pada pusat-pusat pelatihan atlet.

Pembinaan atlet yang benar, akan meningkatkan prestasi atlet. Pembinaan atlet pada pencak silat mencakup pembinaan fisik dan pembinaan mental pesilat. Pembinaan fisik dalam mendukung prestasi ditekankan pada kemampuan komponen biomotor yang harus dimiliki oleh atlet seperti daya tahan (endurance), kekuatan otot (muscle strenght), kecepatan (speed), daya ledak otot (muscle explosive power), Ketangkasan (agility), Kelentukan (flexibility), keseimbangan (balance)
(Joko Subroto, 1994; Suharno, 1985: 24; Iwan Setiawan, 1991: 112). Keterpaduan kemampuan-kemampuan yang dimiliki pesilat akan mempengaruhi ketercapaian target prestasi. Target prestasi pesilat mencakup perpaduan dari kemampuan elakan/tangkisan, pukulan, tendangan, teknik menjatuhkan dan teknik penguncian dalam menghadapi lawan tanding di arena pertandingan.

Dalam Pencak silat unsur-unsur kondisi fisik kelincahan sangatlah penting, disamping didukung dengan adanya unsur-unsur kondisi fisik yang lainnya. Kelincahan dibutuhkan oleh seorang pesilat karena sangat menentukan keberhasilan dalam melancarkan serangan, menghindari pukulan atau bahkan kemampuan menghindari serangan kemudian membalas menyerang.

Dalam olah raga pencak silat diperlukan ketrampilan fisik yang prima mencakup usaha bela serang dalam suatu pertandingan. Bentuk aktifitas utama dalam pertandingan silat adalah menendang, memukul, menangkis, menghindar, meloncat, membanting dan menjatuhkan lawan. Untuk menjadi pesilat yang tangguh diperlukan kondisi fisik yang prima yang mencakup kesegaran jantung paru, kekuatan otot, daya tahan, kelenturan dan kelincahan disamping koordinasi dan ketrampilan (Reilly, 1996), dan untuk memperoleh kondisi fisik tersebut melalui pelatihanpelatihan fisik dari senam untuk pemanasan, penguluran, gerakan-gerakan bela diri dasar, latihan ketrampilan bela 
serang, dll yang dilakukan secara intensif dalam satu fase pelatihan yang didasarkan pada kurikulum pendidikan dan latihan pencak silat di masing-masing perguruan.

Kelincahan merupakan satu indikator kondisi fisik atlet untuk dapat tampil prima dalam suatu pertandingan. Kelincahan dapat menunjukkan kemampuan merubah arah dan posisi tubuh dengan cepat dan tepat pada waktu sedang bergerak, tanpa kehilangan keseimbangan dan kesadaran akan posisi tubuhnya (Harsono, 1980: 172; Iwan Setiawan, 1991:116). Kelincahan terkait erat dengan kelentukan dan keseimbangan.

Bentuk-bentuk latihan kelincahan gerak tubuh secara general yang acap dilakukan adalah meliputi lari bolak-balik (shuttle run), lari zig zag, lari dengan formasi angka delapan, squat thrust, latihan lompat-lompat, lari naik-turun tangga. (Iwan Setiawan, 1991 : 116-118).

\section{METODE PENELITIAN}

Penelitian kuantitatif ini dilakukan dengan desain Quasi eksperimental three treatment counterbalanced-balanced design, yang dapat digambarkan sebagai berikut:

$\mathrm{X} 1 \rightarrow \mathrm{X} 2 \quad$ (kelompok latihan lari

bolak-balik)

$\mathrm{X} 3 \rightarrow \mathrm{X} 4 \quad$ (kelompok latihan lari zig-

zag)

$\mathrm{X} 5 \rightarrow \mathrm{X} 6 \quad$ (kelompok latihan lari formasi 8 dan Z).

Teknik pengambilan sampel dalam penelitian ini menggunakan metoda purposive sampling dengan jumlah sampel sebanyak 45 pesilat, masing-masing kelompok terdiri dari 15 pesilat. Variabel dan instrumen dalam penelitian ini adalah: variabel bebas berupa latihan lari, dan variabel terikat berupa kemampuan biomotor yang terdiri dari kelincahan, kecepatan reaksi, kelentukan dan keseimbangan dari pesilat sebagai sampel. Definisi operasional dalam penelitian ini antara lain: (1) latihan peningkatan kemampuan biomotor kelincahan adalah berupa latihan lari bolak-balik, lari zig-zag dan lari dengan formasi angka delapan dan huruf $\mathrm{Z}$, (2) Atlet pencak silat atau pesilat adalah seorang yang mempunyai kemampuan dan kesiapan gerakan bela serang.

Prosedur pengukuran variable dalam penelitan ini adalah: (1) tes kelincahan pesilat dengan lari bolak-balik (shuttle run), (2) kecepatan reaksi dengan tes lari cepat 6 detik, (3) fleksibilitas atau kelentukan dengan Sit and reach test, dan (4) keseimbangan dengan The Stork Stand Test. Sedangkan komponen pendukung berupa berat badan diukur dengan timbangan, tinggi badan dengan pita ukur antopometri (meteran). Pengukuran dilakukan sebelum dan sesudah perlakuan. Pesilat mendapat perlakuan selama 6 minggu dengan waktu perlakuan 3 kali perminggu.

Teknik analisis data dengan uji Wilcoxon dan uji Kruskal Wallis test. Hasil perlakuan dan kaitan pengaruhnya diketahui dengan menguji perbedaan inter dan antar kelompok. Untuk mengetahui peningkatan atau kemajuan dengan mean different. Batas kemaknaan hasil uji statistik adalah $\mathrm{p}=0.05$ (5\%), bila nilai $\mathrm{p}>0.05=$ tidak bermakna dan bila nilai $\mathrm{p}<0.05=$ bermakna

\section{HASIL PENELITIAN}

Didapatkan 45 atlet yang memenuhi kriteria menjadi subyek penelitian yang memenuhi kriteria penerimaan penelitian. Kemudian dilakukan randomisasi sederhana untuk 
membagi subyek ke dalam 3 kelompok latihan yaitu latihan lari bolak-balik, lari zig zag (z) dan lari formasi angka 8 . Kelompok lari bolak-balik berjumlah 15 orang, kelompok lari zig-zag berjumlah 15 orang, dan kelompok lari formasi angka 8 berjumlah 15 orang. Data variable biomotor diperoleh dari pengukuran fleksibilitas, keseimbangan, kelincahan dan kecepatan, kepada masing-masing subyek dilakukan perlakuan selama 6 minggu, seminggu 3 kali, yang diawali dengan pre tes dan post tes setelah 6 minggu perlakuan.

Sebelum diberi perlakuan, kelompok-kelompok yang dibentuk dalam penelitian ini diuji perbedaannya terlebih dahulu. Hasil uji perbedaan antar kelompok latihan adalah sebagai berikut :

Tabel 1.

Perbedaan Hasil Pre test

\begin{tabular}{|c|c|c|c|c|c|}
\hline Kelompok & & $\begin{array}{c}\text { Flexibili } \\
\text { tas }\end{array}$ & $\begin{array}{c}\text { Keseimba } \\
\text { ngan }\end{array}$ & $\begin{array}{c}\text { Kelincaha } \\
\text { n }\end{array}$ & $\begin{array}{c}\text { Kecepata } \\
\text { n }\end{array}$ \\
\hline \multirow{3}{*}{$\begin{array}{l}\text { Lari bolak- } \\
\text { balik }\end{array}$} & $N$ & 15 & 15 & 15 & 15 \\
\hline & Mean & 4.53 & 1.53 & 1.93 & 1.47 \\
\hline & $S D$ & 0.52 & 0.74 & 1.03 & 0.64 \\
\hline \multirow[t]{3}{*}{ Lari zig-zag } & $N$ & 15 & 15 & 15 & 15 \\
\hline & Mean & 4.53 & 3.07 & 2.80 & 3.60 \\
\hline & $S D$ & 0.52 & 1.53 & 0.94 & 0.51 \\
\hline \multirow{3}{*}{$\begin{array}{l}\text { Lari formasi } \\
\text { angka } 8\end{array}$} & $N$ & 15 & 15 & 15 & 15 \\
\hline & Mean & 4.40 & 2.53 & 3.07 & 2.80 \\
\hline & $S D$ & 0.51 & 1.13 & 1.16 & 0.94 \\
\hline \multirow{3}{*}{$\begin{array}{l}\text { Hitungan } \\
\text { Statistik }\end{array}$} & $X 2$ & 0.696 & 10.476 & 8.276 & 26.865 \\
\hline & $P$ & 0.706 & 0.005 & 0.016 & 0.001 \\
\hline & $P^{*}$ & $P>0.05$ & $P<0.05$ & $\mathrm{P}<0.05$ & $P<0.05$ \\
\hline $\begin{array}{c}\text { Keteranga } \\
\mathbf{n}\end{array}$ & & $\begin{array}{c}T d k \\
\text { signifika } \\
n \\
\end{array}$ & signifikan & signifikan & Signifikan \\
\hline \multicolumn{6}{|c|}{$\begin{array}{l}\text { dilakukan diperoleh } \mathrm{X} 2 \text { hitung sebagai } \\
\text { berikut: Pada fleksibilitas } \mathrm{X} 2=0.696 \text {, } \\
\text { dengan } \mathrm{p}=0.706 \text { dimana } \mathrm{P}>0.05 \text { yang } \\
\text { berarti tidak terdapat perbedaan bermakna } \\
\text { antar ketiga kelompok latihan lari. Hal ini } \\
\text { berarti bahwa ketiga kelompok berangkat }\end{array}$} \\
\hline
\end{tabular}

dari kemampuan dasar yang sama (setara) untuk fleksibilitas, pada keseimbangan $\mathrm{X} 2=10.476$, dengan $\mathrm{p}=0.005$ dimana $\mathrm{P}<0.05$ yang berarti terdapat perbedaan bermakna antar ketiga kelompok latihan lari, pada kelincahan didapatkan 8.276, dengan $\mathrm{p}=0.016$ dimana $\mathrm{P}<0.05$ yang berarti terdapat perbedaan bermakna antar ketiga kelompok latihan lari, pada kecepatan didapatkan 26.865, dengan $\mathrm{p}=0.001$ dimana $\mathrm{P}<0.05$ yang berarti terdapat perbedaan bermakna antar ketiga kelompok latihan lari.

Dari kelompok diatas berangkat dari keadaan yang tidak sama untuk keseimbangan, kelincahan dan kecepatan, namun yang dipakai dasar acuan penentuan pretest adalah kemampuan awal yang dimiliki subyek saat itu, dan yang menjadi acuan hasil akhir adalah persentase kenaikan mean atau mean different yang dicapai.

Analisis data mengenai komponen biomotor setelah diberikan perlakuan diperoleh hasil sebagai berikut:

Uji inter kelompok latihan

1. Komponen Fleksibilitas

\section{Tabel 2}

Perbedaan Hasil Pre-Post test pada komponen Fleksibilitas

\begin{tabular}{llcccccl}
\hline Kelompok & & $\mathbf{N}$ & $\begin{array}{c}\text { Mea } \\
\mathbf{n}\end{array}$ & $\mathbf{S D}$ & $\mathbf{Z}$ & $\mathbf{P}$ & $\mathbf{P} *$ \\
\hline Lari bolak- & Pre & 15 & 4.53 & 0.51 & - & 0.31 & $\mathrm{P}>0$. \\
balik & test & & & 6 & 1.00 & 7 & 05 \\
& Post & 15 & 4.40 & 0.63 & 0 & & \\
Lari zig-zag & test & & & 2 & & & \\
& Pre & 15 & 4.53 & 0.51 & - & 0.31 & $\mathrm{P}>0$. \\
& test & & & 6 & 1.00 & 7 & 05 \\
& Post & 15 & 4.67 & 0.48 & 0 & & \\
Lari formasi & test & & & 8 & & & \\
angka 8 & Pre & 15 & 4.40 & 0.50 & - & 0.01 & $\mathrm{P}<0$. \\
& test & & & 7 & 2.44 & 4 & 05 \\
& Post & 15 & 4.80 & 0.41 & 9 & & \\
\hline & test & & & 4 & & & \\
\hline
\end{tabular}

Dari uji Wilcoxon yang dilakukan diperoleh $\mathrm{Z}=-1.000$ pada kelompok lari bolak-balik, dengan $\mathrm{P}=0.317$ dimana $p>0.05$ yang berarti tidak terdapat perbedaan bermakna dalam kelompok lari 
bolak-balik sebelum dan setelah perlakuan.

Dari uji Wilcoxon yang dilakukan diperoleh $Z=-1.000$ pada kelompok lari zig-zag, dengan $\mathrm{P}=0.317$ dimana $\mathrm{p}>0.05$ yang berarti tidak terdapat perbedaan bermakna dalam kelompok lari zig-zag sebelum dan setelah perlakuan.

Dari uji Wilcoxon yang dilakukan diperoleh $\mathrm{Z}=-2.449$ pada kelompok lari zig-zag kombinasi angka 8 , dengan $\mathrm{P}=$ 0.014 dimana $p<0.05$ yang berarti terdapat perbedaan bermakna dalam kelompok lari zig-zag kombinasi angka 8 sebelum dan setelah perlakuan.

2. Komponen Keseimbangan

\section{Tabel 3}

Perbedaan Hasil Pre-Post test pada Komponen keseimbangan

\begin{tabular}{|c|c|c|c|c|c|c|c|}
\hline Kelompok & & $\mathbf{N}$ & $\begin{array}{l}\text { Mea } \\
n\end{array}$ & SD & $\mathbf{Z}$ & $\mathbf{P}$ & $\mathbf{P}^{*}$ \\
\hline \multirow[t]{2}{*}{$\begin{array}{l}\text { Lari bolak- } \\
\text { balik }\end{array}$} & $\begin{array}{l}\text { Pre } \\
\text { test }\end{array}$ & 15 & 1.53 & $\begin{array}{c}0.74 \\
3\end{array}$ & $\begin{array}{c}- \\
2.62\end{array}$ & $\begin{array}{c}0.00 \\
9\end{array}$ & $\begin{array}{c}\mathrm{P}<0 . \\
05\end{array}$ \\
\hline & $\begin{array}{l}\text { Post } \\
\text { test }\end{array}$ & 15 & 2.67 & $\begin{array}{c}1.17 \\
5\end{array}$ & 2 & & \\
\hline \multirow[t]{2}{*}{ Lari zig-zag } & $\begin{array}{l}\text { Pre } \\
\text { test }\end{array}$ & 15 & 3.07 & $\begin{array}{c}1.53 \\
4\end{array}$ & $\begin{array}{c}- \\
0.89\end{array}$ & $\begin{array}{c}0.37 \\
4\end{array}$ & $\begin{array}{c}\mathrm{P}>0 . \\
05\end{array}$ \\
\hline & $\begin{array}{l}\text { Post } \\
\text { test }\end{array}$ & 15 & 3.67 & $\begin{array}{c}1.17 \\
5\end{array}$ & 0 & & \\
\hline \multirow[t]{2}{*}{$\begin{array}{l}\text { Lari formasi } \\
\text { angka } 8\end{array}$} & $\begin{array}{l}\text { Pre } \\
\text { test }\end{array}$ & 15 & 2.53 & $\begin{array}{c}1.12 \\
5\end{array}$ & 2.12 & $\begin{array}{c}0.03 \\
4\end{array}$ & $\begin{array}{c}\mathrm{P}<0 . \\
05\end{array}$ \\
\hline & $\begin{array}{l}\text { Post } \\
\text { test }\end{array}$ & 15 & 3.40 & $\begin{array}{c}1.29 \\
8\end{array}$ & 4 & & \\
\hline
\end{tabular}

Dari uji Wilcoxon yang dilakukan diperoleh $\mathrm{Z}=-2.622$ pada kelompok lari bolak-balik, dengan $\mathrm{P}=0.009$ dimana $\mathrm{p}<0.05$ yang berarti terdapat perbedaan bermakna dalam kelompok lari bolakbalik sebelum dan setelah perlakuan. Dari uji Wilcoxon yang dilakukan diperoleh $\mathrm{Z}$ $=-0.890$ pada kelompok lari zig-zag, dengan $\mathrm{P}=0.374$ dimana $\mathrm{p}>0.05$ yang berarti tidak terdapat perbedaan bermakna dalam kelompok lari zig-zag sebelum dan setelah perlakuan. Dari uji Wilcoxon yang dilakukan diperoleh $\mathrm{Z}=-2.124$ pada kelompok lari zig-zag kombinasi angka 8 , dengan $\mathrm{P}=0.034$ dimana $\mathrm{p}<0.05$ yang berarti terdapat perbedaan bermakna dalam kelompok lari formasi angka 8 sebelum dan setelah perlakuan.

\section{Komponen kelincahan}

Tabel 4.

Perbedaan Hasil Pre-Post test Pada Komponen kelincahan

\begin{tabular}{llcccccc}
\hline Kelompok & & $\mathbf{N}$ & $\begin{array}{c}\text { Mea } \\
\mathbf{n}\end{array}$ & $\mathbf{S D}$ & $\mathbf{Z}$ & $\mathbf{P}$ & $\mathbf{P} *$ \\
\hline Lari bolak- & Pre & 15 & 1.93 & 1.03 & - & 0.02 & $\mathrm{P}<0$. \\
balik & test & & & 3 & 2.23 & 5 & 05 \\
& Pos & 15 & 2.27 & $\begin{array}{c}1.28 \\
0\end{array}$ & 6 & & \\
& t & & & 0 & & & \\
Lari zig-zag & test & & & & & & \\
& Pre & 15 & 2.80 & 0.94 & - & 0.00 & $\mathrm{P}<0$. \\
& test & & & 1 & 2.72 & 6 & 05 \\
& Pos & 15 & 3.73 & 0.70 & 4 & & \\
Lari formasi & t & & & 4 & & & \\
angka 8 & test & & & & & & \\
& Pre & 15 & 3.07 & 1.16 & - & 0.30 & P $>0$. \\
& test & & & 3 & 1.02 & 5 & 05 \\
& Pos & 15 & 3.33 & 1.04 & 7 & & \\
& t & & & 7 & & & \\
\hline
\end{tabular}

Dari uji Wilcoxon yang dilakukan diperoleh $\mathrm{Z}=-2.236$ pada kelompok lari bolak-balik, dengan $\mathrm{P}=0.025$ dimana $\mathrm{p}<0.05$ yang berarti terdapat perbedaan bermakna dalam kelompok lari bolakbalik sebelum dan setelah perlakuan. Dari uji Wilcoxon yang dilakukan diperoleh $\mathrm{Z}$ $=-2.724$ pada kelompok lari zig-zag, dengan $\mathrm{P}=0.006$ dimana $\mathrm{p}<0.05$ yang berarti terdapat perbedaan bermakna dalam kelompok lari zig-zag sebelum dan setelah perlakuan. Dari uji Wilcoxon yang dilakukan diperoleh $\mathrm{Z}=-1.027$ pada kelompok lari zig-zag kombinasi angka 8 , dengan $\mathrm{P}=0.305$ dimana $\mathrm{p}>0.05$ yang berarti tidak terdapat perbedaan bermakna dalam kelompok lari zig-zag kombinasi angka 8 sebelum dan setelah perlakuan. 
4. Komponen Kecepatan

Tabel 5

Perbedaan Hasil Pre-Post Test Pada Komponen Kecepatan

\begin{tabular}{llcccccc}
\hline Kelompok & & $\mathbf{N}$ & $\begin{array}{c}\text { Mea } \\
\text { n }\end{array}$ & SD & $\mathbf{Z}$ & $\mathbf{P}$ & P* \\
& & & & & & \\
\hline $\begin{array}{l}\text { Lari bolak- } \\
\text { balik }\end{array}$ & Pre & 15 & 1.47 & 0.64 & - & 0.31 & $\mathrm{P}>0$. \\
& test & & & 0 & 1.00 & 7 & 05 \\
& Post & 15 & 1.60 & 0.82 & 0 & & \\
Lari zig-zag & test & & & 8 & & & \\
& Pre & 15 & 3.60 & 0.50 & - & 0.20 & P>0. \\
& test & & & 7 & 1.26 & 6 & 05 \\
& Post & 15 & 3.87 & 0.64 & 5 & & \\
Lari formasi & test & & & 0 & & & \\
angka 8 & Pre & 15 & 2.80 & 0.94 & - & 0.41 & $\mathrm{P}>0$. \\
& test & & & 1 & 0.81 & 4 & 05 \\
& Post & 15 & 2.93 & 0.79 & 6 & & \\
\hline & test & & & 9 & & & \\
\hline
\end{tabular}

Dari uji Wilcoxon yang dilakukan diperoleh $\mathrm{Z}=-1.000$ pada kelompok lari bolak-balik, dengan $\mathrm{P}=0.317$ dimana p>0.05 yang berarti tidak terdapat perbedaan bermakna dalam kelompok lari bolak-balik sebelum dan setelah perlakuan. Dari uji Wilcoxon yang dilakukan diperoleh $\mathrm{Z}=-1.265$ pada kelompok lari zig-zag, dengan $\mathrm{P}=0.206$ dimana $\mathrm{p}>0.05$ yang berarti tidak terdapat perbedaan bermakna dalam kelompok lari zig-zag sebelum dan setelah perlakuan. Dari uji Wilcoxon yang dilakukan diperoleh $\mathrm{Z}=-0.816$ pada kelompok lari zig-zag kombinasi angka 8 , dengan $\mathrm{P}=$ 0.414 dimana $p>0.05$ yang berarti tidak terdapat perbedaan bermakna dalam kelompok lari formasi angka 8 sebelum dan setelah perlakuan.

Analisi data setelah perlakuan

\section{Tabel 6}

Perbedaan Hasil Post test

\begin{tabular}{llcccc}
\hline \multicolumn{1}{c}{ Kelompok } & & Flexibilitas & Keseimbangan & Kelincahan & Kecepatan \\
\hline Lari bolak- & $\mathrm{N}$ & 15 & 15 & 15 & 15 \\
balik & Mean & 4.40 & 2.67 & 2.27 & 1.60 \\
& $\mathrm{SD}$ & 0.632 & 1.175 & 1.280 & 0.828 \\
Lari zig-zag & $\mathrm{N}$ & 15 & 15 & 15 & 15 \\
& Mean & 4.67 & 3.67 & 3.73 & 3.87 \\
& $\mathrm{SD}$ & 0.488 & 1.175 & 0.704 & 0.640 \\
Lari formasi & $\mathrm{N}$ & 15 & 15 & 15 & 15 \\
angka 8 & $\mathrm{Mean}$ & 4.80 & 3.40 & 3.33 & 2.93 \\
& $\mathrm{SD}$ & 0.414 & 1.298 & 1.047 & 0.799 \\
Hitungan & $\mathrm{X} 2$ & 3.951 & 5.065 & 10.940 & 28.051 \\
Statistik & $\mathrm{P}$ & 0.139 & 0.079 & 0.004 & 0.001 \\
& $\mathrm{P} *$ & $\mathrm{P}>0.05$ & P $>0.05$ & $\mathrm{P}<0.05$ & $\mathrm{P}<0.05$ \\
\hline Keterangan & & Tdk & Tidak & signifikan & Signifikan \\
& & signifikan & Signifikan & & \\
\hline
\end{tabular}

Dari uji Kruskal Wallis yang dilakukan diperoleh $\mathrm{X} 2$ hitung sebagai berikut: Pada fleksibilitas X2 $=3.951$, dengan $\mathrm{p}=0.139$ dimana $\mathrm{P}>0.05$ yang berarti tidak terdapat perbedaan bermakna antar ketiga kelompok latihan lari. Hal ini berarti bahwa ketiga ketiga tidak mengalami perbedaan yang berarti selama diberikan latihan lari, pada keseimbangan $\mathrm{X} 2=5.065$, dengan $\mathrm{p}=0.079$ dimana $\mathrm{P}>0.05$ yang berarti tidak terdapat perbedaan bermakna antar ketiga kelompok latihan lari, pada kelincahan = 10.940, dengan $\mathrm{p}=0.004$ dimana $\mathrm{P}<0.05$ yang berarti terdapat perbedaan bermakna antar ketiga kelompok latihan lari, pada kecepatan $=28.051$, dengan $\mathrm{p}=0.001$ dimana $\mathrm{P}<0.05$ yang berarti terdapat perbedaan bermakna antar ketiga kelompok latihan lari.

\section{Persentase Peningkatan Komponen Biomotor}

Diperoleh berbagai hasil yang tidak sama dalam setiap kelompok latihan lari bolak-balik, lari zig-zag dan lari formasi 8. Komponen fleksibilitas, keseimbangan, kelincahan dan kecepatan mengalami perbedaan di antar dan inter kelompok. Untuk itu dapat dilihat pula dari perubahan mean different pada masing-masing kelompok perlakuan.

Tabel 7

Persentase Peningkatan Komponen Biomotor

\begin{tabular}{|c|c|c|c|c|c|}
\hline Kelompok & $\begin{array}{c}\text { Komponen } \\
\text { Biomotor }\end{array}$ & $\begin{array}{c}\text { Mean } \\
\text { awal }\end{array}$ & $\begin{array}{l}\text { Mean } \\
\text { Akhir }\end{array}$ & $\begin{array}{c}\text { Mean } \\
\text { Different }\end{array}$ & $\begin{array}{c}\text { Persentase } \\
\text { Kenaikan } \\
(\%)\end{array}$ \\
\hline Lari & Fleksibilitas & 4.53 & 4.40 & -0.13 & -2.87 \\
\hline bolak- & Keseimbangan & 1.53 & 2.67 & 1.14 & 74.51 \\
\hline \multirow[t]{2}{*}{ balik } & Kelincahan & 1.93 & 2.27 & 0.34 & 17.62 \\
\hline & Kecepatan & 1.47 & 1.60 & 0.13 & 8.84 \\
\hline Lari zig- & Fleksibilitas & 4.53 & 4.67 & 0.14 & 3.09 \\
\hline \multirow[t]{3}{*}{ zag } & Keseimbangan & 3.07 & 3.67 & 0.6 & 19.54 \\
\hline & Kelincahan & 2.80 & 3.73 & 0.93 & 33.21 \\
\hline & Kecepatan & 3.60 & 3.87 & 0.27 & 7.5 \\
\hline Lari & Fleksibilitas & 4.40 & 4.80 & 0.4 & 9.09 \\
\hline formasi & Keseimbangan & 2.53 & 3.40 & 0.87 & 34.39 \\
\hline \multirow[t]{2}{*}{ angka 8} & Kelincahan & 3.07 & 3.33 & 0.26 & 6.47 \\
\hline & Kecepatan & 2.80 & 2.93 & 0.13 & 4.64 \\
\hline
\end{tabular}


Dari tabel dapat dilihat bahwa persentase kenaikan tertinggi pada fleksibilitas terdapat pada kelompok lari formasi angka 8, dengan persentase sebesar $9.09 \%$, pada keseimbangan persentase tertinggi terdapat pada lari bolak-balik, dengan persentase sebesar $74.51 \%$, pada kelincahan persentase tertinggi terdapat pada lari zig-zag, dengan persentase sebesar $33.21 \%$, pada kecepatan persentase tertinggi terdapat pada lari bolak-balik, dengan persentase sebesar $8.84 \%$.

\section{PEMBAHASAN}

Kelincahan merupakan satu indikator kondisi fisik atlet untuk dapat tampil prima dalam suatu pertandingan. Kelincahan dapat menunjukkan kemampuan merubah arah dan posisi tubuh dengan cepat dan tepat pada waktu sedang bergerak, tanpa kehilangan keseimbangan dan kesadaran akan posisi tubuhnya (Harsono, 1980: 172; Iwan Setiawan, 1991 :116). Kelincahan terkait erat dengan kelentukan dan keseimbangan. Bentuk-bentuk latihan kelincahan meliputi lari bolak-balik (shuttle run), lari zig zag, lari angka delapan, squat thrust, latihan lompatlompat, lari naik-turun tangga. (Iwan Setiawan, 1991 : 116-118). Dalam penelitian ini terdapat perbedaan bermakna pada komponen kelincahan dan kecepatan pada ketiga kelompok, tidak terdapat perbedaan pada fleksibilitas dan keseimbangan. Dengan angka X2 kelincahan $=10.940 \quad(\mathrm{p}<0.05), \quad \mathrm{X} 2$ kecepatan $=28.051(\mathrm{p}<0.05)$, sedang $\mathrm{X} 2$ fleksibilitas $=3.951 \quad(\mathrm{p}>0.05), \quad \mathrm{X} 2$ keseimbangan $=5.065 \quad(\mathrm{p}>0.05)$. Pada perbedaan inter kelompok didapatkan perbedaan yang bermakna pada kelompok latihan lari formasi angka 8 pada fleksibilitas, kelompok lari bolak balik dan lari zig-zag kombinasi angka 8 pada keseimbangan, serta kelompok lari bolakbalik dan kelompok lari zig-zag untuk komponen kelincahan. Pada penghitungan persentase kenaikan mean dapat terlihat bahwa persentase kenaikan tertinggi pada fleksibilitas terdapat pada kelompok lari formasi angka 8, dengan persentase sebesar $9.09 \%$. Sedangkan pada keseimbangan persentase tertinggi terdapat pada lari bolak-balik, dengan persentase sebesar $74.51 \%$. Sedangkan pada kelincahan persentase tertinggi terdapat pada lari zig-zag, dengan persentase sebesar $33.21 \%$. Sedangkan pada kecepatan persentase tertinggi terdapat pada lari bolak-balik, dengan persentase sebesar $8.84 \%$.

\section{KESIMPULAN DAN SARAN}

Dari perhitungan statistik diperoleh kesimpulan bahwa ada perbedaan bermakna antara latihan bolakbalik, lari zig-zag dan lari formasi angka 8 terutama pada kelincahan, dan kecepatan $(p<0.05)$. Metode latihan lari bolak-balik berguna untuk meningkatkan keseimbangan dan kecepatan, metode latihan lari zig-zag berguna untuk meningkatkan kelincahan, dan metode lari formasi angka 8 berguna untuk meningkatkan fleksibilitas.

\section{DAFTAR RUJUKAN}

Dangsina Moeloek dan Arjatmo Tjokronegoro. 1984. Kesehatan dan Olah raga. Jakarta : Fakultas Kedokteran UI.

Grana, William A, et all. 1988. Advances in sport Medicine and Fitness. Chicago: Book Medical Publisher, Inc 
Hardianto Wibowo. 1994. Pencegahan dan Penatalaksanaan Cedera Olah Raga. Jakarta : Penerbit Buku Kedokteran EGC.

Joko Subroto. 1994. Pembinaan Pesilat. Solo : CV. Aneka.

Jones, Kim. 1996. Human Movement Explained. Oxford : ButterworthHeinemann.

Maryun Sudirohadiprodjo. 1982. Pelajaran Pesilat. Jakarta : Bratara

Mulyono B. 2000. Pengukuran dan Evaluasi Olah raga. Surakarta : UNS

Pate, Russel R., et all.(terjemaahan). 1993. Dasar-dasar Ilmiah Kepelatihan. Semarang : IKIP Semarang Press.

Robergs, Robert A. 1997. Exercise Physiology. St. Luis : Mosby

Soekarman. 1989. Dasar-dasar Olahraga untuk Pembina, Pelatih dan Atlet. Jakarta : Haji Masagung.

Srihati Waryati. 1995. Pesilat. Surakarta : UNS.

Sucipto, 2001. Pendekatan Ketrampilan Taktis dalam Pembelajaran Pesilat. Jakarta : Depdiknas 